\title{
PENGARUH BRAND IMAGE POLITEKNIK PARIWISATA PALEMBANG TERHADAP MINAT CALON MAHASISWA
}

\author{
Mustika Permatasari $^{1^{*}} \&$ Muhammad Halfi Indra Syaputra $^{2}$ \\ ${ }^{1}$ Politeknik Pariwisata Palembang, ${ }^{2}$ Politeknik Pariwisata Medan
}

\begin{tabular}{|c|c|}
\hline Article History & Abstrak \\
\hline Submitted: Jan 6, 2020 & \multirow{5}{*}{$\begin{array}{l}\text { Minat dari konsumen terlihat dari pandangan dari citra atau image yang } \\
\text { melekat pada suatu produk atau perusahaan. Untuk mendapatkan } \\
\text { perhatian dari suatu konsumen untuk masuk di perguruan tinggi yang } \\
\text { terpenting dilihat dari citra atau image dari suatu produk atau } \\
\text { perusahaan tersebut. Pengujian pengaruh Brand Image dilakukan untuk } \\
\text { mengukur minat masuk calon mahasiswa baru di Politeknik Pariwisata } \\
\text { Palembang dengan menggunakan uji validitas, uji reliabilitas dan uji } \\
\text { asumsi klasik. Tujuan dari uji yang dilakukan adalah untuk melihat hasil } \\
\text { pengaruh Brand Image terhadap minat calon mahasiswa baru. Pada } \\
\text { penelitian ini meggunakan metode kualitatif deskriptif. Berdasarkan } \\
\text { hasil penelitian ditemukan bahwa ada pengaruh nilai signifikan dari uji } \\
\text { F sebesar o,ooo yang lebih dari kecil dari o,oo5, dimana dari variabel } \\
\text { bebasnya yaitu Image (XI) dan Informasi (X2) berpengaruh secara } \\
\text { serempak terhadap minat calon mahasiswa baru di politeknik pariwisata } \\
\text { Palembang. Dimana pada uji regresi linear untuk variabel image ini } \\
\text { terhitung 5,649 dengan probablitas o,ooo < o,oo5 dan untuk variabel } \\
\text { informasi didapatkan } 6,254 \text { dengan probablitas o,ooo< o,oo5 yang } \\
\text { mempunyai arti yaitu adanya suatu pengaruh yang signifikan diantara } \\
\text { keduanya. }\end{array}$} \\
\hline Accepted : Feb 19, 2020 & \\
\hline Published : Feb 20, 2020 & \\
\hline Kata Kunci & \\
\hline $\begin{array}{l}\text { Brand Image, minat calon } \\
\text { mahasiswa, politeknik } \\
\text { pariwisata. }\end{array}$ & \\
\hline
\end{tabular}

\section{PENDAHULUAN}

Pariwisata adalah suatu industri raksasa dunia yang dapat memajukan pertumbuhan ekonomi secara cepat. Dimana mesin untuk perkembangan ekonomi, pariwisata sudah dapat terbukti dan dengan terbentuknya dampak positif dari hasil devisa, dan dengan terciptanya lapangan kerja dan pendapatan, dan juga dapat mempengaruhi dari konsumen domestik juga (Croes \& Vanegas, 2008).

Pendirian Politeknik Pariwisata Palembang ini didasari kebutuhan SDM profesional di bidang kepariwisataan, sehingga dirasa perlu didirikan lembaga pendidikan pariwisata yang mencetak tenaga profesional di bidang pariwisata yang dibutuhkan. Bahkan, kesan (Image) perguruan tinggi seringkali dianggap lebih penting dibanding dengan kualitas yang berkaitan dengan layanan kepada mahasiswa. Citra yang baik dimata customer sangat penting di dalam perguruan tinggi. Citra menjadi hal yang harus diperhatikan oleh perguruan tinggi yaitu untuk menjaga nama baik dari perguruan tinggi tersebut sehingga dapat mempengaruhi daya minat customer untuk dapat masuk di perguruan tinggi tersebut. Jadi citra ini benar-benar harus dijaga dan dipertahankan untuk mendapatkan hasil yang diharapkan. Kepuasan dari customer adalah tujuan akhir dari tingkat keberhasilan dari perguruan tinggi tersebut, sehingga untuk mendaptkan hasil akhir yang diinginkan citra baik tersebut haruslah dijaga. 
Minat customer untuk masuk didalam perguruan tinggi dipengaruhi oleh citra atau nama baik dari perguruan tinggi tersebut.

Untuk mendapatkan perhatian dan akhirnya calon mahasiswa menentukan minat masuk membuat citra menjadi suatu hal yang penting untuk mempengaruhi minat masuk. Ini disebabkan karena pada saat promosi, lulusan-lulusan, calon mahasiswa tidak hanya memberikan respons terhadap barang atau jasa yang ditawarkan, tetapi calon mahasiswa akan memberikan respons terhadap lingkungan yang diciptakan universitas itu.

\section{METODE DAN FOKUS PENELITIAN}

\section{Metode Penelitian}

Penelitian ini menggunakan metode penelitian deskriptif-kuantitatif. Menurut Freddy Rangkuti (2001), metode penelitian deskriptif adalah suatu metode penelitian yang bertujuan untuk memberikan gambaran tentang keadaan perusahaan untuk kemudian diolah menjadi data yang diperlukan oleh peneliti.

\section{Operasionalisasi Variabel}

Untuk variabel penelitian merupakan sesuatu yang dapat berbentuk apa saja yang telah ditetapkan oleh peneliti dan telah dipelajari sehingga dapat diperoleh informasi mengenai hal tersebut, sehingga dapat ditarik kesimpulan (Sugiyono, 2013). Variabel yang biasa digunakan pada penelitian ini dapat diklasifikasikan menjadi: (1) variabel independen (bebas), yaitu variabel yang menjelaskan dan mempengaruhi variabel lain, dan (2) variabel dependen (terikat), yaitu variabel yang dijelaskan dan dipengaruhi oleh variabel independen.

\section{Hipotesis Penelitian}

Subjek Penelitian

Subjek penelitian ini merupakan para mahasiswa baru di Perguruan Tinggi Politeknik Pariwisata Palembang. Para responden merupakan sumber daya yang telah memilih dan lolos seleksi sebagai peserta didik Perguruan Tinggi Politeknik Pariwisata Palembang.

Teknik Analisa Data

Dari kuesioner yang telah disebarkan kepada subjek penelitian terhimpun 212 lembar kuesioner. Kuesioner tersebut diolah menggunakan alat SPSS dengan analisis regresi linear ganda (Multiple Linear Regression/MLR).

Pengolahan Data

Berdasarkan kuesioner yang disebar kepada mahasiswa baru Politeknik Pariwisata Palembang pada bulan Agustus 2018, terhimpun 212 kuesioner yang dapat dijadikan informasi utama pada pengujian hipotesis pada penelitian ini. Terdapat 5 (lima) jenis uji asumsi klasik yaitu uji multikolinearitas, autokolerasi, heteroskedositas, normalitas, dan lineritas yang akan dibahas pada poin-poin selanjutnya. 
Profil Responden

Responden pada penelitian ini merupakan mahasiswa baru Politeknik Pariwisata Baru angakatan masuk 2018. Kusioner disebar kepada 350 mahasiswa dengan jumlah kuesioner yang kembali sebanyak 212 lembar. Dari 212 lembar kuesioner yang berhasil didapatkan dengan profil responden sebagai berikut:

Tabel 1. Profil Responden

\begin{tabular}{|l|l|l|}
\hline Deskripsi Profil & Jumlah & Persentase \\
\hline Umur & & \\
$16-18$ tahun & 85 & $85.4 \%$ \\
$19-21$ tahun & 13 & $13.2 \%$ \\
$>21$ tahun & 2 & $1.4 \%$ \\
\hline Kota Asal & & \\
Palembang & 10 & $10.3 \%$ \\
Jawa Barat & 3 & $2.8 \%$ \\
lainnya & 87 & $86.9 \%$ \\
\hline Pengalaman Bekerja & & \\
Sudah Pernah & 12 & $12.3 \%$ \\
Belum Pernah & 88 & $87.7 \%$ \\
\hline Pendidikan Terakhir & & \\
SMA IPA & 50 & $50 \%$ \\
SMA IPS & 24 & $23.6 \%$ \\
SMK Pariwisata & 14 & $13.7 \%$ \\
dll & 36 & $35.7 \%$ \\
\hline Sumber Informasi & & \\
Kerabat non alumni & 60 & $59.4 \%$ \\
Kerabat alumni & 32 & $31.6 \%$ \\
Website & 11 & $11.3 \%$ \\
Online berita & 16 & $15.6 \%$ \\
Dan lainnya & 18 & $17.9 \%$ \\
\hline
\end{tabular}

Pada Tabel 1 tersebut dapat dilihat informasi profil responden pada kategori umur menandakan bahwa sebanyak 85.4\% merupakan mahasiswa berumur 16-18 tahun atau dengan kata lain adalah responden memanfaatkan usia kelulusan sekolah menengah atas langsung mengecam pendidikan tinggi. Dimana para responden mayoritas tidak hanya dari daerah Palembang justru merupakan para pendatang dari kota lainnya. Sebagian besar sebanyak $87.7 \%$ responden belum pernah berpengalaman dalam dunia kerja, hal ini terjadi dengan asumsi mayoritas responden berasal dari usia lulus sekolah menegah atas. Adapun profil responden sebanyak 50\% memiliki latar belakang pendidikan SMA jurusan IPA, dimana jurusan tersebut memiliki latar belakang keilmuan yang bertolak belakang. Pada kategori sumber informasi, mayoritas 59.4\% responden mengetahui Politeknik Pariwisata Palembang dari kerabat dengan latar belakang bukan dari alumni PTP (Perguruan Tinggi Pariwisata). Hal ini menunjukan pengaruh kerabat mendominasi sumber informasi utama dari para responden.

Uji Validitas dan Reliabilitas Data

Validitas yang diajukan dalam tes untuk menilai tingkat akurasi instrumen penelitian. Reliabilitas digunakan untuk menguji konsistensi instrumen penelitian - 
seberapa baik skala mengukur konsep (Hair, Black, Babin, Anderson \& Tatham, 2006). Tingkat konsistensi ini menunjukan bahwa instrument kuesioner yang digunakan dapat diandalkan dalam mendapatkan data primer. Jika nilai Cronbach's Alpha lebih besar dari o.7 maka item-item pada kuesioner yang digunakan dinyatakan reliabel atau konsisten (Imam Ghazali, 2011).

\section{Uji Multikolinearitas}

Uji multikolinearitas merupakan suatu uji yang dilaukan untuk memastikan bahwa pada model regresi ada interkorelasi atau kolineritas dengan variabel bebas. Untuk Interkorelasi ini meupakan suatu bentuk hubungan linear yang kuat antara variabel bebas dengan variabel prediktor yang lain pada suatu model regresi. Interkorelasi ini juga dapat dilihat melalui nilai koefisien antara variabel bebas, dimana nilai VIF dan Tolerance, nilai Eigenvalue dan Condition Index, serta nilai standar error koefisien beta atau koefisien regresi parsial.

\section{Uji Autokolerasi}

Uji autokorelasi dikenal dengan uji Durbin Watson yang merupakan suat analisis statistik yang digunakan untuk memahami adakah korelasi variabel yang ada di dalam model prediksi dengan perubahan waktu. Dan oleh hal itu, jika asumsi autokorelasi terjadi pada suatu model prediksi, maka nilai disturbance tidak akan berpasangan dengan bebas, melainkan berpasangan secara autokorelasi. Dan untuk Uji Durbin Watson merupakan suatu uji autokorelasi yang menilai adanya autokorelasi pada residual.

\section{Uji Heteroskedastisitas}

Heteroskedastisitas adalah salah satu yang dapat mengakibatkan model regresi linear sederhana tidak akurat, juga mengakibatkan penggunaan metode kemungkinan maksimum dalam mengestimasi parameter (koefisien) regresi akan terganggu. Akibat akan terjadi jika apabila terdapat keadaan heterokedastisitas yang merupakan sulit mengukur standar deviasi yang sebenarnya, sehingga menghasilkan standar suatu deviasi yang lebar maupun terlalu sempit. Jika tingkat error dari varians terus bertambah, maka tingkat kepercayaan akan semakin sempit.

\section{Uji Normalitas}

Adapun beberapa cara dalam melakukan pengujian normalitas pada data salah satunya adalah menggunakan Chi-Square. Metode Chi-Square atau X2 untuk Uji Goodness of Fit Distribusi Normal menggunakan pendekatan penjumlahan penyimpangan data observasi tiap kelas dengan nilai yang diharapkan.

\section{Uji Lineritas}

Untuk Uji linearitas berfugsi untuk memahami yaitu apakah dua variabel mempunyai huungan linear yang signifikan. Untuk pengujian yang dapat dilihat yaitu dengan bagaimana variabel (X) dapat mempengaruhi variabel (Y), yaitu dapat dilihat baik dari yang berbanding lurus ataupun yang berbanding terbalik. Untuk uji ini biasanya dilakukan untuk ppersyaratan dalam analisa korelasi dan regresi. Untuk suatu 
pengujian pada SPSS dengan menggunakan Test for Linearity dengan pada taraf signifikansi 0,05. Dua variabel dikatakan mempunyai hubungan yang linear bila signifikansi (Linearity) kurang dari 0,05.

\section{HASIL DAN PEMBAHASAN}

\section{Uji Validitas dan Reliabilitas}

Uji validitas dan reliabilitas pasa penelitian ini menggunakan korelasi product moment. Hal ini dilakukan untuk mengetahui intrumen yang dibuat dalam mengumpulkan data dinyatakan tepat dan dapat diandalkan. Pada penelitian ini uji validitas dilakukan dengan cara membandingkan angka $r$ hitung dengan $r$ tabel. Dari hasil penghitungan terhadap tiap item pertanyaan dari masing-masing variabel didapatkan data bahwa angka pada item 1 hingga item 7 pada instrument pertanyaan "Brand Image" Poltekpar Palembang menunjukan angka terkecil o.763 sedangkan angka terbesar 0.901. Sedangkan, hasil pengujian item pertanyaan ke 1 hingga pertanyaan ke 22 pada kelompok insturmen pertanyaan "informasi" memperoleh angka terkecil sebesar 0.576 dan tertinggi sebesar 0.823 . Pada data kelompok instumen pertanyaan "motivasi" melalui item pertanyaan no 1 hingga nomor 12 mendapatkan rentang angka sebesar 0.528 untuk angka terendah dan 0.696 untuk angka tertinggi. Seluruh angka tersebut dapat dilihat pada tabel lampiran A dimana seluruh nilai $r$ hitung yang diolah menunjukan lebih dari $r$ tabel yaitu o.3. Hal tersebut membuktikan bahwa instrumen yang digunakan sudah tepat atau valid untuk dijadikan alat pengumpul data primer pada penelitian ini.

Uji reliabilitas pada penelitian ini menggunakan metode membandingkan angka Cornbach Alpha. Hasil pada tabel 1 menunjukan angka Cronbach Alpha sebesar o.957 dimana nilai tersebut menunjukan angka yang lebih besar dari o.6. Cronbach Alpha yang lebih besar dari o.6 menunjukan bahwa instrument penelitian yang digunakan untuk mengukur variabel pada penelitan ini dapat dinyatakan handal atau reliabel. Dengan kata lain, data yang dimiliki melalui instrument pada penelitian ini dapat diolah lebih lanjut pada uji asumsi klasik.

Tabel 1 Reliability Statistics

\begin{tabular}{|l|l|l|}
\hline Cronbach's Alpha & $\begin{array}{l}\text { Cronbach's Alpha Based on } \\
\text { Standardized Items }\end{array}$ & of Items \\
\hline .957 & .969 & 41 \\
\hline
\end{tabular}

\section{Uji Asumsi Klasik}

Terdapat 4 pengujian diantaranya adalah uji normalitas, multikolonieritas, heteroskedasitisitas, dan autokorelasi. Keempat uji ini merupakan syarat wajib pada uji parametik sebelum dilakukannya pengujian analisa linearitas (dalam penelitian ini hasil akhir data akan diolah menggunakan regresi linear berganda). Pada penjelasan selanjutnya menunjukan hasil yang didapat dari masing-masing uji asumsi klasik tersebut. 


\section{Uji Normalitas}

Asumsi klasik pada uji normalitas di penelitian ini dilakukan pengecekan melalui tabel histogram. Tabel 2 histogram di bawah ini menggambarkan bentuk lonceng, hal ini secara subyektif peneliti dapat menyimpulkan bahwa data berdistribusi normal. Normalitas data juga dapat dilihat dari tabel P-P Plot dimana sebaran data pada Tabel 3 menunjukan bentuk yang terkonsentrasi pada garis tengah atau mengikuti garis linear. Hal ini memperkuat bahwa data yang telah dihimpun terdistribusi dengan normal.

Tabel 2. Histogram Uji Normalitas

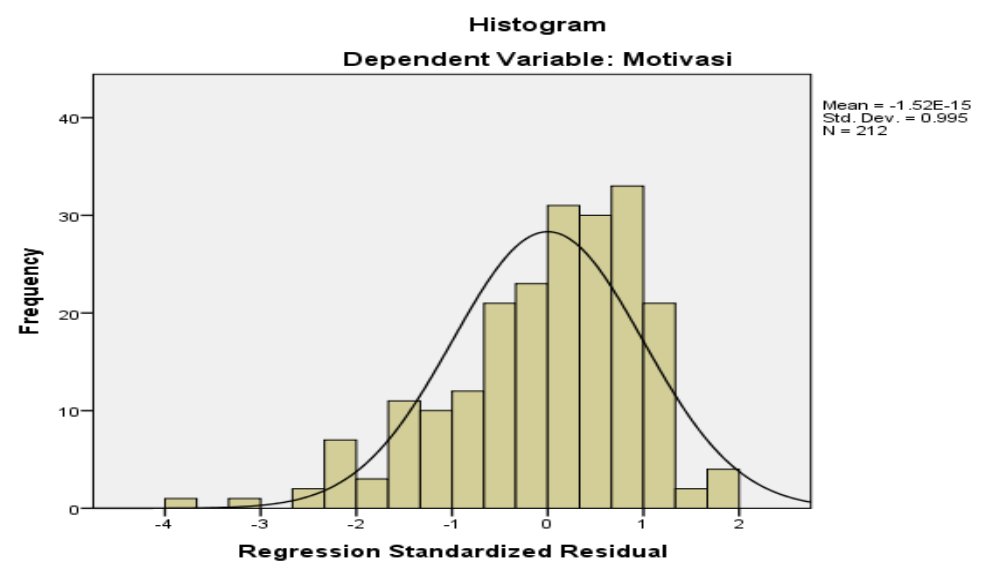

Tabel 3. P-P Plot Uji Normalitas

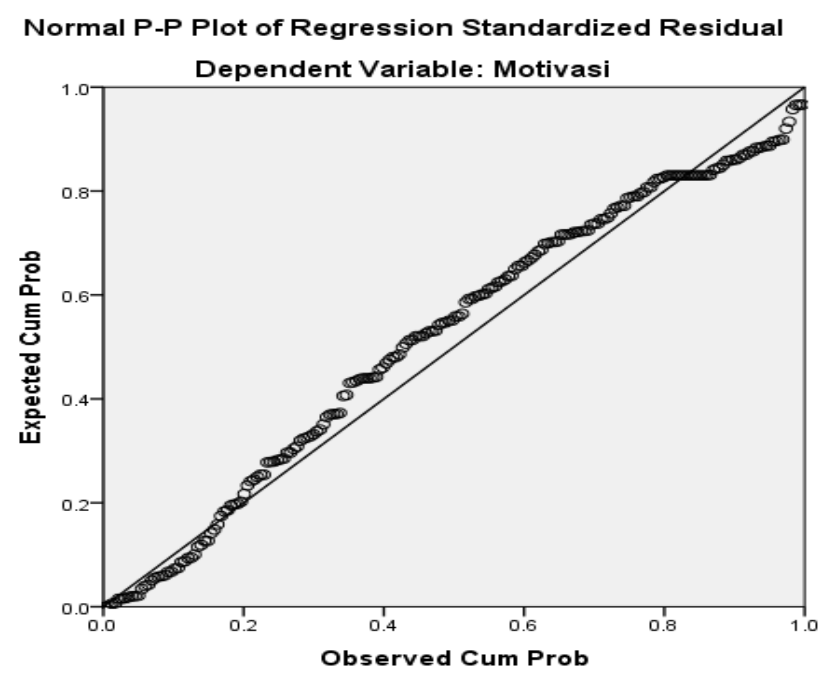




\section{Uji Multikolinieritas}

Uji Multikolinieritas yang dilakukan dalam penelitian ini menghasilkan data VIF tidak lebih besar dari nilai 10. Hal tersebut membuktikan bahwa tidak terjadi multikolinieritas untuk masing-masing tabel.

Tabel. 4 Coefficients ${ }^{\mathrm{a}}$ Uji Multikolinieritas

\begin{tabular}{|c|c|c|c|c|c|c|c|c|}
\hline \multirow{2}{*}{\multicolumn{2}{|c|}{ Model }} & \multicolumn{2}{|c|}{$\begin{array}{c}\text { Unstandardized } \\
\text { Coefficients }\end{array}$} & \multirow{2}{*}{$\begin{array}{l}\text { Standardized } \\
\text { Coefficients } \\
\text { Beta }\end{array}$} & \multirow[t]{2}{*}{$\mathrm{t}$} & \multirow[t]{2}{*}{ Sig. } & \multicolumn{2}{|c|}{ Collinearity Statistics } \\
\hline & & B & Std. Error & & & & Tolerance & VIF \\
\hline \multirow{3}{*}{1} & (Constant) & 8.179 & 3.978 & & 2.056 & .041 & & \\
\hline & Image & .712 & .126 & .385 & 5.649 & .000 & .438 & 2.285 \\
\hline & Informasi & .232 & .037 & .426 & 6.254 & .000 & .438 & 2.285 \\
\hline
\end{tabular}

a. Dependent Variabel: Motivasi

\section{Uji Heteroskedastisitas}

Pada uji ini yang telah dijelaskan adalah bagian dari uji asumsi klasik yang harus dilakukan pada penelitian lineritas variabel penelitian. Uni heteroskedastisitas untuk melihat apakah terdapat kesamaan varians dari residual satu pengamatan ke pengamatan yang lain tetap atau disebut homoskedastisitas.

Deteksi heteroskedastisitas pada penelitian ini dilakukan dengan uji Glejser. Uji Glejser pada penelitian ini menunjukan variabel Image $\left(\mathrm{X}_{1}\right)$ memiliki nilai signifikansi sebesar 0.733 dan Informasi (X2) menunjukan angka signifikansi sebesar 0.96o. Kedua nilai tersebut menampilkan signifikansi lebih besar daripada 0.05. Maka, dapat diartikan tidak terjadi heteroskedastisitas atau terjadi kesamaan (homoskedastisitas) variance dari residual satu pengamatan ke pengamatan lain.

Tabel 5. Coefficients ${ }^{\mathrm{a}}$ Uji Heterskedasititas

\begin{tabular}{|c|c|c|c|c|c|c|}
\hline \multirow{2}{*}{\multicolumn{2}{|c|}{ Model }} & \multicolumn{2}{|c|}{ Unstandardized Coefficients } & \multirow{2}{*}{$\begin{array}{c}\begin{array}{c}\text { Standardized } \\
\text { Coefficients }\end{array} \\
\text { Beta }\end{array}$} & \multirow[t]{2}{*}{$\mathrm{t}$} & \multirow[t]{2}{*}{ Sig. } \\
\hline & & $\mathrm{B}$ & Std. Error & & & \\
\hline \multirow{3}{*}{1} & (Constant) & 5.659 & 2.393 & & 2.365 & .019 \\
\hline & Image & -.026 & .076 & -.036 & -.341 & .733 \\
\hline & Informasi & -.001 & .022 & -.005 & -.050 & .960 \\
\hline
\end{tabular}

a. Dependent Variabel: RES2 
Metode Scatter Plot yaitu dengan memplotkan nilai ZPRED (nilai prediksi) dengan SRESID (nilai residualnya). Model yang baik didapatkan jika tidak terdapat pola tertentu pada grafik, seperti mengumpul di tengah, menyempit kemudian melebar atau sebaliknya melebar kemudian menyempit.

\section{Uji Autokorelasi}

Uji autokorelasi pada penelitian ini menggunakan pengukuran pada nilai Durbin Watson (DW). Pada tabel 6 di bawah ini menunjukan angka 1.915 dimana syarat untuk lolos pada uji ini adalah ketika nilai DW berada diantara nilai dU dan 4-dU pada Tabel Durbin Watson. Dengan begitu dihasilkan asumsi nilai $1.7887<1.915<(4-1.7887)$ yang berarti nilai DW pada data tersebut dinyatakan bebas dari autokorelasi.

Tabel.6 Model Summary ${ }^{\mathrm{b}}$ Autokorelasi

\begin{tabular}{|l|l|l|l|l|l|l|}
\hline Model & $\mathrm{R}$ & R Square & $\begin{array}{l}\text { Adjusted } \\
\text { Square }\end{array}$ & $\begin{array}{l}\text { Std. Error of the } \\
\text { Estimate }\end{array}$ & Durbin-Watson \\
\hline 1 & $.759^{\mathrm{a}}$ & .576 & .572 & 5.425 & 1.915 \\
\hline
\end{tabular}

a. Predictors: (Constant), Informasi, Image

b. Dependent Variabel: Motivasi

\section{Uji Linearitas}

Pada tabel 7 Anova Tabel Uji Linearitas akan dilihat nilai Sig. linearity untuk setiap tabel bebas dengan tabel terikat dapat dibandingan dengan tingkat signifikansi $(\alpha)$. Nilai Sig. linearity menunjukkan sejauh mana tabel bebas dapat berbanding tepat di garis lurus. Apabila nilai Sig. linearity lebih kecil dari tingkat signifikansi $(\alpha)$, maka regresi linier dapat dipergunakan untuk menjelaskan pengaruh antara tabel variabel yang ada. Diperoleh nilai sig. pada baris linearity sebesar o.ooo dimana angka tersebut menunjukan nilai yang lebih kecil dari pada o.05, maka dapat disimpulkan bahwa data tersebut telah berhasil memenuhi syarat lineritas.

Tabel 7 ANOVA Tabel Uji Linearitas

\begin{tabular}{|c|c|c|c|c|c|c|c|}
\hline & & & Sum of Squares & df & Mean Square & $\mathrm{F}$ & Sig. \\
\hline \multirow{7}{*}{$\begin{array}{l}\text { Motivasi * } \\
\text { Informasi }\end{array}$} & & (Combined) & 9467.123 & 46 & 205.807 & 6.759 & .000 \\
\hline & Doturoon & Linearity & 7401.391 & 1 & 7401.391 & 243.074 & .000 \\
\hline & Grouns & Deviation & & & & & \\
\hline & & from & 2065.732 & 45 & 45.905 & 1.508 & .033 \\
\hline & & Linearity & & & & & \\
\hline & \multicolumn{2}{|c|}{ Within Groups } & 5024.099 & 165 & 30.449 & & \\
\hline & \multicolumn{2}{|l|}{ Total } & 14491.222 & 211 & & & \\
\hline
\end{tabular}




\section{Uji Regresi Linear Berganda}

Berdasarkan peta model asumsi Gambar 1 dilakukan pengujian terhadap hipotesis dalam penelitian ini. Hipotesis pertama $\left(\mathrm{H}_{1}\right)$ mengasumsikan bahwa citra atau Brand Image memengaruhi motivasi dalam keputusan pemilihan Politeknik Pariwisata Palembang menjadi studi selanjutnya para responden untuk level perguruan tinggi. Adapun Hipotesis ke dua $\left(\mathrm{H}_{2}\right)$ diasumsikan bahwa Informasi yang didapatkan responden memengaruhi tingkat motivasi dalam pengambilan keputusan kuliah di Politeknik Pariwisata Palembang. Sedangkan Hipotesis ke tiga $\left(\mathrm{H}_{3}\right)$ menyelidiki bahwa vaiabel Brand Image dan informasi dapat memengaruhi motivasi dalam pengambilan keputusan kuliah di Politeknik Pariwisata Palembang secara bersamaan.

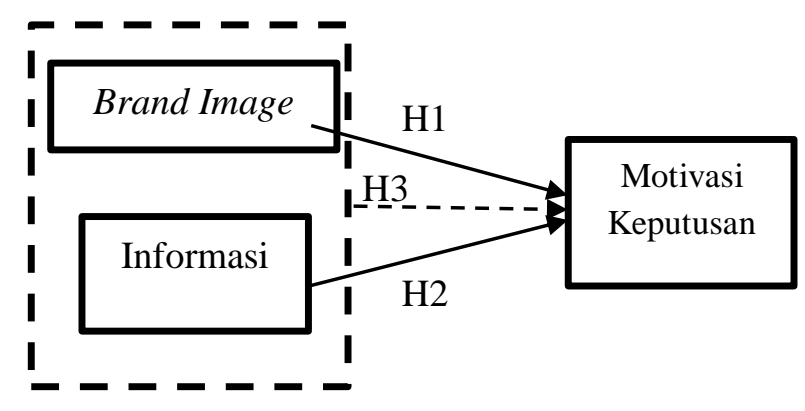

\section{Gambar 1. Model Hipotesis}

Dari hasil pengolahan data pada SPSS menghasilkan beberapa nilai analisa menunjukan dari sejumlah tabel. Pada Tabel 8 merupakan matrik korelasi antara variabel image dengan motivasi diperoleh nilai r sebesar 0.704 dengan nilai probabilitas sebesar 0.000 yaitu kurang dari 0.05 , maka Ho ditolak. Hal tersebut berarti bahwa ada hubungan / korelasi yang signifikan antara image dengan motivasi. Nilai variabel informasi sebesar $\mathrm{r}=0.715$ bertanda positif menandakan bahwa variabel bergerak secara searah dengan semakin banyak informasi yang didapat maka motivasi untuk kuliah di Politeknik Pariwisata Palembang akan semakin besar.

Tabel 8. Correlations Regresi Linier Berganda

\begin{tabular}{|ll|l|l|l|}
\hline & & Motivasi & Image & Informasi \\
\hline \multirow{2}{*}{ Pearson Correlation } & Motivasi & 1.000 & .704 & .715 \\
& Image & .704 & 1.000 & .750 \\
& Informasi & .715 & .750 & 1.000 \\
Sig. (1-tailed) & Motivasi &. & .000 & .000 \\
& Image & .000 &. & .000 \\
$\mathrm{~N}$ & Informasi & .000 & .000 &. \\
& Motivasi & 212 & 212 & 212 \\
& Image & 212 & 212 & 212 \\
& Informasi & 212 & 212 & 212 \\
\hline
\end{tabular}

Pada Tabel 9 model summary terdapat model 1 dan 2. Model 1 menjelaskan

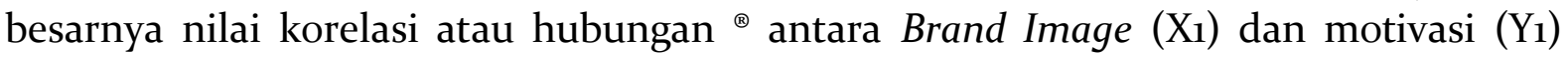


menunjukan nilai 0.715. Dari output tersebut diperoleh koefisien determintasi (R2) pada model 1 sebesar 0.511 yang berarti adanya pengaruh variabel bebas (Brand Image) terhadap variabel terikat (motivasi) adalah sebesar $51.1 \%$. Sedangkan pada model 2 untuk menjelaskan besarnya nilai korelasi ${ }^{\circledR}$ antara Brand Image (X1) dan informasi (X2) terhadap motivasi (Y) yaitu sebesar 0.759 dan menjelaskan besarnya presentase pengaruh variabel Brand Image (X1) dan informasi $\left(\mathrm{X}_{2}\right)$ terhadap motivasi (Y) menunjukan nilai sebesar 0.576 atau presenntasi 57.6\%. Maka, disimpulkan besarnya pengaruh nilai Brand Image (X1) terhadap motivasi $(\mathrm{Y})$ sebesar 51.1\%, dan pengaruh informasi (X2) terhadap motivasi (Y) senilai 6.5\% (57.6\% - 51.1\%).

Tabel 9. Model Summary ${ }^{\mathrm{c}}$ Regresi Linier Berganda

\begin{tabular}{|l|r|r|r|r|r|}
\hline Model & R & R Square & Adjusted R Square & $\begin{array}{l}\text { Std. Error of the } \\
\text { Estimate }\end{array}$ & Durbin-Watson \\
\hline 1 & $.715^{\mathrm{a}}$ & .511 & .508 & 5.810 & 1.915 \\
\hline
\end{tabular}

a. Predictors: (Constant), Informasi

b. Predictors: (Constant), Informasi, Image

c. Dependent Variabel: Motivasi

Dari hasil pengujian pertama untuk hipotesis 1 dan 2 didapatkan nilai sig. untuk Brand Image dan informasi sama-sama mendapatkan nilai sebesar o.ooo. Hal tersebut menerangkan bahwa masing-masing variabel tersebut memiliki nilai kurang dari 0.05, maka dari itu hipotesis $\mathrm{H}_{1}$ dan $\mathrm{H}_{2}$ diterima. Brand Image mempengaruhi secara signifikan motivasi responden dalam mengambil keputusan kuliah di Politeknik Pariwisata Palembang. Beigitu juga variabel informasi menunjukan hasil yang sama terhadap motivasi pengambilan keputusan.

Tabel 10. Coefficients ${ }^{\mathrm{a}}$ Regresi Linier Berganda

\begin{tabular}{|c|c|c|c|c|c|c|}
\hline \multirow{2}{*}{\multicolumn{2}{|c|}{ Model }} & \multicolumn{2}{|c|}{ Unstandardized Coefficients } & \multirow{2}{*}{$\begin{array}{c}\begin{array}{c}\text { Standardized } \\
\text { Coefficients }\end{array} \\
\text { Beta }\end{array}$} & \multirow[t]{2}{*}{$\mathrm{t}$} & \multirow[t]{2}{*}{ Sig. } \\
\hline & & $\mathrm{B}$ & Std. Error & & & \\
\hline \multirow{3}{*}{1} & (Constant) & 8.179 & 3.978 & & 2.056 & .041 \\
\hline & Image & .712 & .126 & .385 & 5.649 & .000 \\
\hline & Informasi & .232 & .037 & .426 & 6.254 & .000 \\
\hline
\end{tabular}

a. Dependent Variabel: Motivasi

Pada hasil SPSS dalam menguji hipotesis ke tiga $\left(\mathrm{H}_{3}\right)$ dapat dilihat dari hasil tabel ANOVA dibawah ini. Pada Tabel 10 menunjukan bahwa nilai sig. F sebesar o.ooo. Dengan kata lain nilai yang dihasilkan pada pengolahan data regresi linear berganda menunjukan lebih kecil dari o.05. Maka, hipotesis ke tiga $\left(\mathrm{H}_{3}\right)$ tidak dapat ditolak 
bahwa dinyatakan melalui hasil tabel tersebut variabel Brand Image (X1) dan informasi (X2) mempengaruhi secara bersamaan motivasi pengambilan keputusan.

Tabel 11. ANOVA ${ }^{a}$ Regresi Linier Berganda

\begin{tabular}{|c|c|c|c|c|c|c|}
\hline \multicolumn{2}{|c|}{ Model } & Sum of Squares & $\mathrm{df}$ & Mean Square & $\mathrm{F}$ & Sig. \\
\hline & Regression & 8340.648 & 2 & 4170.324 & 141.710 & $.000^{\mathrm{b}}$ \\
\hline 1 & Residual & 6150.574 & 209 & 29.429 & & \\
\hline & Total & 14491.222 & 211 & & & \\
\hline
\end{tabular}

a. Dependent Variabel: Motivasi

b. Predictors: (Constant), Informasi, Image

Maka kesimpulan pada uji regresi linear berganda ini adalah nilai Brand Image thitung 5.649 dengan probabilitas $0.000<0.05$ memiliki arti adanya pengaruh signifikan. Untuk variabel informasi diperoleh thitung 6.254 dengan probalitas juga $0.000<0.05$ juga berarti memiliki pengaruh yang signifikan.

\section{PENUTUP}

\section{Kesimpulan}

Hasil pengujian instumen pertanyaan pada 7 indikator pertanyaan terlihat bahwa variabel Brand Image Politeknik Pariwisata Palembang menunjukkan angka terkecil 0.763 dengan indikator tingkat sikap perusahaan dalam bertanggung jawab kepada konsumen jika terjadi masalah yaitu bagaimana tingkat pelayanan baik terhadap pengaduan, kritik dan saran dari mahasiswa dan orang tua mahasiswa. Sedangkan angka terbesar 0.901 dengan indikator dimana Politeknik Pariwisata Palembang mudah dihubungi melalui digital media baik berupa website dan akun Instagram.

Hasil pengujian instumen pertanyaan pada 22 indikator pertanyaan informasi memperoleh angka terkecil sebesar 0.576 dengan indikator dimana Politeknik Pariwisata menampilkan visual gamar untuk mudah dipahami dan tertinggi sebesar o.823 dengan indikator tingkat persuasi calon mahasiswa yang dinilai mampu membuat para calon mahasiswa termotivasi untuk memilih Politeknik Pariwisata Palembang.

Hasil pengujian instumen pertanyaan motivasi melalui item pertanyaan no 1 hingga nomor 12 mendapatkan rentang angka sebesar 0.528 untuk angka terendah dimana indikatornya adalah para Calon Mahasiswa melakukan evaluasi terlebih dahulu mengenai layanan pendidikan di Politeknik Pariwisata Palembang maupun di Perguruan Tinggi lainnya dan 0.696 untuk angka tertinggi dimana indikatornya adalah tingkat pencarian informasi lebih mudah diakses dan termotivasi untuk mempelajari lebih jauh.

Matrik korelasi antara variabel image dengan motivasi diperoleh nilai r sebesar 0.704 dengan nilai probabilitas sebesar 0.000 yaitu kurang dari 0.05, sehingga Ho ditolak. Hal tersebut diartikan yaitu adanya hubungan / korelasi yang signifikan antara image dengan motivasi. Nilai variabel informasi sebesar $\mathrm{r}=0.715$ bertanda positif 
menandakan bahwa variabel bergerak secara searah dengan semakin banyak informasi yang didapat maka motivasi untuk kuliah di Politeknik Pariwisata Palembang akan semakin besar. Bahwa citra atau Brand Image mempengaruhi motivasi dalam keputusan pemilihan Politeknik Pariwisata Palembang menjadi studi selanjutnya para responden untuk level perguruan tinggi.

\section{Saran}

Citra dari Politeknik Pariwisata Palembang harus dimulai dari pelayanan yang diberikan kepada calon mahasiswa dan orang tua mahasiswa. Semua informasi dapat tersampaikan dengan jelas, akurat dan dapat dipercaya keabsahannya. Dengan adanya information center yang ada di kampus Politeknik Pariwisata Palembang maka akan membuat para orang tua yakin akan sistem pembelajaran baik dari penerimaan, proses belajar mengajar sampai menjadi lulusan Politeknik Pariwisata Palembang. Kemudahan informasi dapat dimanfaatkan dengan adanya digital media yang memang cocok untuk generasi millenial. Membangun brand adalah proses yang memerlukan waktu jangka panjang, tidak mungkin produk kita menjadi terkenal dengan instan. Hal ini sesuai dengan target Kementerian Pariwisata dalam mem-branding Pesona Indonesia yang dikenal dengan branding, advertising maupun selling (BAS). Banyak sekali para pejabat Pemerintah Daerah yang mendukung adanya kampus Politeknik Pariwisata Palembang salah satu diantaranya adalah Bapak Alex. H Noerdin. Kita dapat mengundang kembali publik figur yang dapat mendorong promosi Kampus Politeknik Pariwisata Palembang terutama yang bergerak di bidang Pariwisata. Adapun cara dalam meningkatkan reputasi Politeknik Pariwisata Palembang dengan menawarkan kegiatan yang berkontribusi terhadap masyarakat. Salah satunya dengan kegiatan Program Corporate Social Responsibility dan melakukan pengabdian kepada masyarakat dengan melakukan kegiatan Table Manner di institusi Pemerintah yang terdekat. Adanya testimoni dari kalangan yang memiliki reputasi tinggi dapat mendongkrak citra dari Kampus ini sendiri.

Informasi yang disampaikan menggunakan bahasa yang mudah dipahami dan dimengerti terutama karena Politeknik Pariwisata merupakan sekolah hospitality dimana banyak menggunakan bahasa asing. Isi materi dari informasi dapat secara jelas disampaikan dan dilakukan dari berbagai sumber yang ada. Adapun penggunaan media digital yang sedang digandrungi oleh kaum millenial. Terutama informasi capaian pembelajaran yang akan didapat ketika para mahasiswa lulus dari Politeknik Pariwisata Palembang.

Untuk menambah minat para calon mahasiswa untuk masuk ke Politeknik Pariwisata Palembang maka ada beberapa strategi yang dapat dilakukan oleh Politeknik Pariwisata Palembang :

1) Akreditasi. Akreditas adalah suatu hal yang paling utama atau yang pertama kali dilihat bagi para calon mahasiswa baru untuk ingin kuliah di perguruan tinggi. Dan ini merupakan salah satu strategi branding yang perlu yang harus diterapkan, akreditasi bukan hanya menarik minat calon mahasiswa akan tetapi juga menarik beberapa instansi untuk bekerjasama. Bagi calon mahasiswa dimana kampus yang mempunyai akreditas yang baik tentunya juga pasti akan mempengaruhi dari dunia kerajanya juga. 
2) Promosi. Kegiatan promosi yaitu suatu komponen yang prioritas dari kegiatan branding dan pemasaran. Tujuan promosi dalam sebuah perusahaan dengan menciptakan kesan yang baik tentang Politeknik Pariwiwsata Palembang, kemudian memberitahukan kepada masyarakat luas tentang Politeknik Pariwisata Palembang dan juga meningatkan keberadaan kampus Politeknik Pariwiwsata Palembang di kawasan Jakabaring. Adapun kegiatan promosi yang dapat dilakukan Politeknik Pariwiwsata Palembang dengan: 1. Melaksanakan advertising dengan menggunakan berbagai media cetak dan elektronik, 2. Interaksi langsung dengan masyarakat dalam berbagai kegiatan seperti Kompetisi, Seminar, Forum Group Discussion, Workshop dan dalam berbagai kunjungan industri yang dilakukan dalam setiap kegiatan, 3. Publisitas dengan meramaikan suatu event rutin seperti car free day, Sudirman Street, festival sungai Musi dan lain sebagainya.

3) Beasiswa. Cara ini sudah tidak asing lagi, dikarenkan dari setiap kampus-kampus pasti mempunyai beasiswa. Dan ini merupakan suatu cara untuk memberikan dampak positif bagi kampus dan juga sangat bermanfaat bagi para penerima, sehingga dapat menarik minat para calon mahasiswa baru.

4) Menonjolkan pembeda atau keunikan tersendiri dari kampus-kampus lain, seperti memiliki Program Studi yang tidak ada di kampus lain, akan tetapi membuka banyak peluang kerja. Keunikan kampus kita adalah dengan bergerak di bidang pariwisata sehingga banyak para Hospitality Industry yang merekrut para mahasiswa untuk menjadi karyawannya.

5) Mempunyai Career Center. Ini merupakan salah satu untuk membantu dari mahasiswa dalam mencari kerja. Dan dengan adanya career center tersebut dapat membantu mereka membantu dalam dunia pekerjaan. Dan hal ini merupakan suatu hal yang perlu diperhatikan bagi mahasiswa baru jika ingin memasuki kampus. Dan career center merupakan bantuan yang disediakan kampus untuk membantu bagi yg tamatan dari perguruan tinggi dapat mendapatkan pekerjaan.

6) Publikasi Kampus Politeknik Pariwisata Palembang dengan memanfaatkan teknologi saat ini yaitu dengan membuat website kampus, dengan adanya website kampus tersebut, orang lain yang ingin mengetahui terkait dari kampus dapat dilihat lengkap melalui website tersebut. Dan untuk isi dari websitenya dapat dilihat mengenai profil, kegiatan-kegiatan yang berlangsung di kampus dan lain sebagainya. Sehingga membuat orang lain tertarik dari kampus kita.

7) Sering Mengikuti Konfrensi Internasional. Yaitu dengan kita mengikuti konferensi Internasional, maka dengan hal itu merupakan salah satu untuk peluang kita dalam menawarkan kampus kita dengan pihak luar atau dengan peserta yang ada di konferensi tersebut. Sehingga dengan seringnya kita mengikuti konferensi tersebut, aka memberikan dampak kepada pendengar jika mendengar untuk nama dari kampus kita.

\section{REFERENSI}

Hair, Black, Babin, Anderson, \& Tatham. (2006). Multivariate Data Analysis Sixth Edition. New Jearsey: Person Education.

Emzir. (2010). Metodologi Penelitian Kualitatif: Analisis Data. Jakarta: PT Raja Grafindo Persada. 
Iskandar.(2008). Metodologi Penelitian Pendidikan dan Sosial (Kuantitaif dan Kualitatif). Jakarta: Gaung Persada Group.

Croes, R. Vanegas. (2008). Cointegration and causality between tourism and poverty reduction. Journal of Travel Research, 47, 95-105.

Ghozali, Imam. (2011). Aplikasi Analisis Multivarite dengan Program SPSS. Semarang: Badan Penerbit Universitas Diponegoro.

Sugiyono. (2013). Metodologi Penelitian Kuantitatif, Kualitatif dan RED. Bandung: Alfabeta.

Freddy, Rangkuti. (2017). Meningkatkan Kinerja Perusahaan melalui Pelayanan Prima Plus Analisis Kasus Jasa Raharja. Jakarta: Gramedia Pustaka. 